\title{
Faktor-faktor yang Mempengaruhi Keberhasilan Berwirausaha
}

\author{
Fibria Anggraini Puji Lestari \\ Universitas Indraprasta PGRI \\ Email : fap102@yahoo.com
}

\begin{abstract}
This research is to fnd out what affect a person who is successful in entrepreneurship. In this study was obtain from questionnaires distributed to student using multiple linear analysis with SPSS 19.00 for windows software.The result of this study showed that variables of interes and talent (0.199), motivation (0.388) and science (0.270) in influencing success entrepreneurship.
\end{abstract}

Keywords : Interes and Talent, Motivation Science

\section{Abstrak}

Penelitian ini untuk mengetahui apa saja yang mempengaruhi seseorang berhasil dalam berwirausaha. Dalam penelitian ini data diperoleh dari kuesioner yang disebar kepada mahasiswa dengan menggunakan analisis liniear berganda dengan software SPSS 19.0 for windows. Hasil penelitian ini menunjukkan bahwa variabel minat dan bakat $(0,199)$, motivasi $(0,388)$, dan ilmu pengetahuan $(0,270)$ dalam mempengaruhi keberhasilan berwirausaha.

Kata Kunci : Minat dan Bakat, Motivasi, Ilmu Pengetahuan

\section{(C) 2019 Jurnal Riset Inspirasi Manajemen dan Kewirausahaan}

\section{PENDAHULUAN}

Di era pasar bebas sekarang ini, dimana keadaan yang di hadapi semakin diperburuk dengan adanya suasana persaingan global (Asean Economic Community) yang akan menyandingkan lulusan Perguruan Tinggi Indonesia dalam kompetisi yang bebas dengan lulusan dari Perguruan Tinggi luar negeri. Para Sarjana lulusan Perguruan Tinggi diharapkan dan diarahkan untuk tidak hanya berorientasi sebagai pencari kerja namun harus siap menjadi pencipta pekerjaan serta menumbuhkan jiwa kewirausahaan mahasiswa. Upaya menumbuhkan jiwa kewirausahaan mahasiswa di perguruan tinggi merupakan alternatif jalan keluar untuk mengurangi tingkat pengangguran serta permasalahan sosial lainnya. Alma (2011) menjelaskan bahwa negara yang maju ditandai dengan banyaknya orang terdidik, dan semakin dirasakan pentingnya dunia wirausaha.

Wirausaha merupakan salah satu pendukung yang menentukan maju mundurnya perekonomian, karena bidang wirausaha mempunyai kebebasan dalam berkarya dan dapat menumbuhkan sikap kemandirian. Jika seseorang mempunyai kemauan dan keinginan serta siap untuk berwirausaha, berarti seseorang itu mampu menciptakan lapangan pekerjaan sendiri, dan tidak perlu mengandalkan orang lain maupun perusahaan lain untuk mendapatkan pekerjaan lagi.

Berdasarkan latarbelakang tersebut penulis ingin meneliti faktor-faktor yang mempengaruhi keberhasilan berwirausaha.

\section{Pengertian Wirausaha}

Menurut KBBI wirausaha merupakan sebuah proses yang disebut creative destruction untuk menghasilkan nilai tambah suatu produk .Wirausaha dikenal dengan nama kewirausahaan yang merupakan suatu ilmu, seni yang mengelola keterbatasan informasi, dana ,sumber daya guna mencapai tujuan hidup yaitu mencari nafkah,berkarir sampai puncak.

Untuk lebih jelas pengertian wirausaha menurut Robert D Hisrich dan Michael P.Peter bahwa "Entrepreneur is one who bring resources,labour, material,and other asset into combination that make their value greater than ." yang artinya seorang wirausaha adalah orang yang dapat mengelola sumber daya, tenaga kerja, bahan produksi dan lainnya untuk dibuat menjadi produk yang lebih mempunyai nilai tambah.

Ciri-ciri yang dimiliki oleh wirausaha:

1. Kreativitas dan keberanian

2. Semangat dan kemauan

3. Mampu dalam menganalisis yang tepat

4. Berani dalam menghadapi resiko

5. Berjiwa kepemimpinan

\section{Pengertian Minat dan Bakat}

Minat merupakan suatu campuran dari perasaan, harapan, pendirian, prasangka, rasa takut atau kecenderungan lain yang mengarahkan individu kepada suatu pikiran tertentu. ( Slameto; 2015; 62). 
Bakat adalah kemampuan dasar seseorang untuk belajar dalam tempo yang relatif pendek dibandingkan orang lain, namun hasilnya justru lebih baik. Bakat merupakan potensi yang dimiliki oleh seseorang sebagai bawaan sejak lahir. Bakat dan minat dapat dipengaruhi dari faktor internal ( faktor bawaan dan kepribadian)dan eksternal ( lingkungan, sekolah dan sosial).

Faktor internal berwirausaha seperti penghasilan,harga diri,perasaan senang )sedangkan factor eksternal yang mempengaruhi minat berwirausaha seperti lingkungan pendiidikan, keluarga,dan lingkungan masyarakat (suhartini.2011).

\section{Mengembangkan Minat Bakat}

\section{Perlu Keberanian}

Keberanian membuat kita mampu menghadapi tantangan atau hambatan, baik yang bersifat fisik dan psikis maupun kendala-kendala sosial atau yang lainnya. Keberanian akan memberikan semangat kepada kita dalam melihat jalan keluar yang berhadapan dengan berbagai kendala yang ada, dan bukan sebaliknya, membuat kita takut dan melarikan diri secara tidak bertanggung jawab.

2. Perlu didukung Latihan

Latihan adalah kunci dari keberhasilan. Latihan digunakan untuk menggerakkan setiap usaha yang kelihatan secara fisik.

3. Perlu didukung Lingkungan

Lingkungan dalam arti yang sangat luas, termasuk manusia, fasilitas, biaya dan kondisi sosial lainnya., yang turut berperan dalam usaha pengembangan bakat dan minat.

4. Perlu memahami hambatan pengembangan bakat dan cara mengatasinya.

Perlu mengidentifikasi dengan baik kendalakendala yang ada, kita kategorikan mana yang mudah diatasi dan mana yang sulit dan dicarikan solusinya.

\section{Motivasi}

Motivasi berasal dari kata Latin "movere" yang berarti dorongan atau daya penggerak. Motivasi ini hanya diberikan kepada manusia, khususnya kepada para bawahan atau pengikut .Dalam teori motivasi yang dikemukakan oleh Maslow ,bahwa seseorang selain untuk memenuhi kebutuhan pokok, rasa aman, kasih sayang,juga membutuhkan pengaktualisasi diri, ingin diakui sebagai orang yang berprestasi didalam dunia wirausaha.

Bentuk-bentuk motivasi meliputi;

1. Motivasi instrinsik yaitu motivasi yang datangnya dari dalam diri individu itu sendiri.

2. Motivasi ekstrinsik yaitu motivasi yang datangnya dari luar individu,
3. Motivasi terdesak yaitu motivasi yang muncul dalam kondisi terjepit dan munculnya serentak serta menghentak dan cepat sekali.

Faktor-faktor yang mempengaruhi motivasi untuk berwirausaha antara lain;

1. Tingkat kematangan pribadi merupakan motivasi yang berasal dari dalam dirinya sendiri, biasanya timbul dari perilaku yang dapat memenuhi kebutuhan sehingga puas dengan apa yang sudah dilakukan,

2. Situasi dan kondisi, motivasi yang timbul berdasarkan keadaan yang terjadi sehingga mendorong memaksa seseorang untuk melakukan sesuatu,

3. Lingkungan kerja atau aktivitas merupakan motivasi yang timbul atas dorongan dalam diri seseorang atau pihak lain yang didasari dengan adanya kegiatan atau aktivitas rutin dengan tujuan tertentu,

4. Tingkat pendidikan mempengaruhi pengetahuan seseorang,

5. Audio Visual (media) motivasi yang timbul dengan adanya informasi yang didapat dari perantara sehingga mendorong atau menggugah hati seseorang untuk melakukan sesuatu,serta sarana dan prasarana dapat mempengaruhi motivasi.Salah satu motivasi yang paling dibutuhkan pelaku usaha adalah keinginannya untuk terus belajar dan menambah keterampilan. Seperti kita ketahui bersama, motivasi belajar menjadi modal awal bagi para pengusaha untuk mengembangkan raksasa bisnisnya.untuk itu kita dapat belajar dari orang-orang sukses di sekitar, belajarlah dari kegagalan yang pernah dialami, dan belajarlah dari sumber ilmu yang tersedia di seluruh belahan dunia.

Adapun faktor-faktor lain yang mempengaruhi motivasi usaha adalah kondisi lingkungan seperti sistem hukum, industri, pasar modal dan kondisi ekonomi nasional mempengaruhi wirausaha, tetapi motivasi wirausahawan akan mengarahkan tindakan wirausaha pada kondisi lingkungan yang berbeda.

\section{Ilmu Pengetahuan}

Ilmu pengetahuan sangatlah penting dalam memulai untuk berwirausaha.Untuk itu ilmu kewirausahaan harus kita pahami dan mengerti karena dalam ilmu kewirausahaan yang merupakan ilmu ,seni dan ketrampilan yang mempelajari bagaimana mengelola semua sumber daya, informasi dan dana yang ada guna memepertahankan hidup.

Dalam konteks bisnis seperti yang telah dikemukakan oleh Thomas w.Zimmerer (1996) bahwa : "Entrepreneurship is the result of a diciplined, systematic process of applying creativity 
and innovations to needs and opportunities in the marketplace ".

Ilmu Kewirausahaan ini diajarkan sebagai ilmu tersendiri yang terdiri dari:

1. Kewirausahaan berisi body of knowledge yang utuh dan nyata, yaitu dengan adanya teori, konsep dan metode ilmiah yang lengkap.

2. Kewirausahaan memiliki dua konsep, yaitu posisi "venture start up" dan "venture growth", dengan demikian jelas tidak masuk dalam kerangka pendidikan manajemen umum (frame work general management courses) yang memisahkan manajemen dari kepemilikan usaha (business ownership).

3. Kewirausahaan merupakan disiplin ilmu yang memiliki obyek tersendiri, yaitu kemampuan untuk menciptakansesuatu yang baru dan berbeda (ability to create new and different things).

4. Kewirausahaan merupakan alat untuk menciptakan pemerataan berusaha dan pemerataan pendapatan (wealth creationprocess an entrepreneurial endeavor by its ownnight, nation's prosperity, individual self reliance) atau kesejahteraan rakyat yang adil dan makmur.

Perkembangan ilmu kewirausahaan sangat pesat, identik dengan perkembangan ilmu bisnis. Pada awalnya ilmu kewirausahaan berkembang dalam bidang perdagangan, namun dengan pesat mengalami evolusi ke berbagai bidang lain seperti industri, pendidikan, kesehatan serta berbagai institusi lain seperti lembaga pemerintah, perguruan tinggi, lembaga swadaya, dalam menciptakan perubahan, pembaharuan dan kemajuan. Kewirausahaan tidak saja digunakan sebagai bisnis jangka pendek, tetapi juga digunakan sebagai alat kehidupan secara umum dalam jangka panjang untuk menciptakan peluang (misalnya di bidang bisnis perusahaan sukses dan memperoleh peluang besar karena memiliki kreativitas dan inovasi yang baik. Melalui kreativitas dan inovatif, wirausaha menciptakan nilai tambah barang sehingga memperoleh berbagai keunggulan termasuk competitive advantage.

\section{Kerangka Pemikiran}

Kerangka pemikiran dalam penelitian ini sebagai berikut:

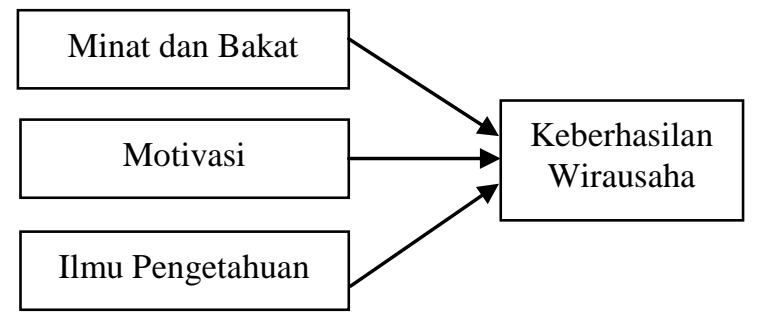

\section{Hipotesis}

Hipotesis penelitian dapat diartikan sebagai jawaban yang bersifat sementara terhadap masalah penelitian, sampai terbukti melalui data yang tekumpul dan harus di uji secara empiris. Berdasarkan uraian kerangka pemikiran di atas, maka hipotesis penelitian adalah sebagai berikut:

$\mathrm{H}_{1} \quad$ : Minat dan bakat berpengaruh terhadap

keberhasilan wirausaha

$\mathrm{H}_{2} \quad$ : Motivasi berpengaruh terhadap keberhasilan wirausaha

$\mathrm{H}_{3} \quad$ : Ilmu pengetahuan berpengaruh terhadap keberhasilan wirausaha.

\section{METODE PENELITIAN}

Dalam penelitian ini menggunakan metode analisis kuantitatif deskriptif.Untuk pengumpulan data penelitian menggunakan metode surve terhadap responden dengan membagikan kuesioner di lapangan.Penelitian ini melibatkan empat komponen yaitu satu variabel tidak bebas dan tiga variabel bebas (independen). Variabel tidak bebasnya adalah keberhasilan berwirausaha ( Y) sedangkan variabel bebas yang terdiri dari: Minat dan bakat $\left(\mathrm{X}_{1}\right)$, motivasi $\left(\mathrm{X}_{2}\right)$,dan ilmu pengetahuan $\left(\mathrm{X}_{3}\right)$.

Tabel

Klasifikasi Variabel dan Indikator

\begin{tabular}{|c|c|c|c|}
\hline $\begin{array}{c}\text { Variabel } \\
\text { Penelitian }\end{array}$ & $\begin{array}{c}\text { Sub } \\
\text { Variabel }\end{array}$ & Indikator & Skala \\
\hline \multirow[t]{3}{*}{$\begin{array}{l}\text { Faktor-faktor yang } \\
\text { mempengaruhi } \\
\text { (Variabel X) }\end{array}$} & $\begin{array}{c}\text { Minat dan } \\
\text { bakat } \\
\left(\mathrm{X}_{1}\right)\end{array}$ & $\begin{array}{l}>\text { Faktor bawaan } \\
>\quad \text { Lingkungann. } \\
> \\
>\text { Sekolah. } \\
\text { Sosial }\end{array}$ & Likert \\
\hline & $\begin{array}{l}\text { Motivasi } \\
\left(\mathrm{X}_{2}\right)\end{array}$ & $\begin{array}{ll}> & \text { Tingkat kematangan } \\
& \text { pribadi. } \\
> & \text { Situasi dan kondisi. } \\
> & \text { Lingkungan. } \\
> & \text { Belajar. } \\
> & \text { Media. }\end{array}$ & Likert \\
\hline & $\begin{array}{c}\text { Ilmu } \\
\text { pengetahu } \\
\text { an }\left(\mathrm{X}_{3}\right)\end{array}$ & $\begin{array}{ll}> & \text { Ilmu kewirausahaan } \\
> & \text { Kreativitas } \\
> & \text { Inovasi } \\
> & \end{array}$ & Likert \\
\hline $\begin{array}{l}\text { Keberhasilan } \\
\text { berwirausaha } \\
\text { (Variabel Y) }\end{array}$ & & 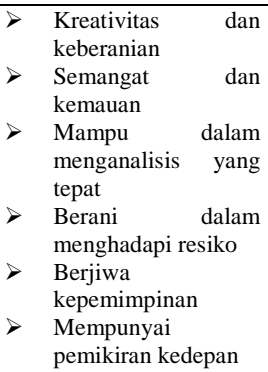 & Likert \\
\hline
\end{tabular}

Sumber : Data yang diolah 2018

Pengumpulan data dalam penelitian ini meliputi :

1. Kajian Pustaka

2. Data kuesioner responden dilapangan. 
Data yang masuk akan diolah dan dianalisis dengan regresi berganda (Sugiyono, 2013:40), dengan formulasi sebagai berikut ;

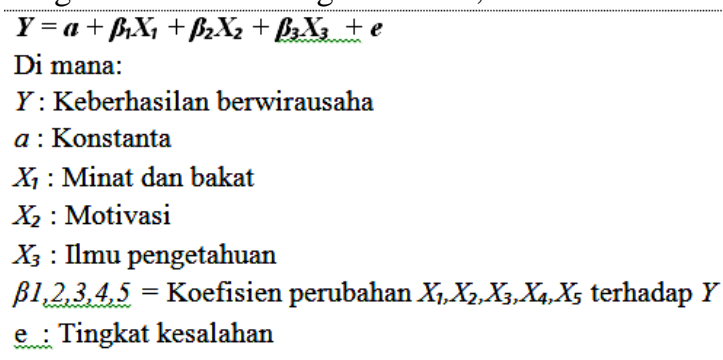

\section{HASIL PENELITIAN DAN PEMBAHASAN}

\section{Responden Berdasarkan Usia}

Tabel

Hasil Responden Berdasarkan Usia

\begin{tabular}{ccc}
\hline USIA & JUMLAH & PRESENTASE \\
\hline 17-25 TAHUN & 38 & $38 \%$ \\
\hline 26-35 TAHUN & 40 & $40 \%$ \\
\hline 36-35 TAHUN & 20 & $20 \%$ \\
\hline 46-55 TAHUN & 7 & $7 \%$ \\
\hline TOTAL & 105 & $100 \%$ \\
\hline
\end{tabular}

Sumber ;Data diolah tahun 2018

Berdasarkan tabel diatas dapat diketahui bahwa usia responden yang terbanyak adalah yang berusia antara 26-35 tahun sebanyak 40 orang (40\%), diikuti dengan usia 17-25 tahun sebanyak 38 orang atau (38\%) dan usia 36-45 tahun sebanyak 20 orang atau (20\%).

\section{Responden Berdasarkan Jenis Kelamin}

Tabel

Responden Berdasarkan Jenis Kelamin

\begin{tabular}{ccc}
\hline KETERANGAN & JUMLAH & PRESENTASE \\
\hline LAKI-LAKI & 50 & $48 \%$ \\
\hline PEREMPUAN & 55 & $52 \%$ \\
\hline TOTAL & 105 & $100 \%$
\end{tabular}

Sumber ; Data diolah tahun 2018

\section{Analisis Regresi Linier Berganda}

1. Uji Signifikansi Parameter Simultan (Uji Statistik F)

Dilakukan untuk menguji apakah secara bersama-sama variabel independen mempunyai pengaruh yang signifikan terhadap variabel dependennya.

\begin{tabular}{|c|c|c|c|c|c|c|}
\hline \multicolumn{7}{|c|}{ ANOVA $^{\circ}$} \\
\hline \multicolumn{2}{|c|}{ Model } & $\begin{array}{l}\text { Sum of } \\
\text { Squares }\end{array}$ & Df & Mean Square & $\mathrm{F}$ & Sig. \\
\hline \multirow[t]{3}{*}{1} & Regression & 614.983 & 3 & 204.994 & 3.098 & $.000^{\circ}$ \\
\hline & Residual & 6683.074 & 101 & 66.169 & & \\
\hline & Total & 7298.057 & 104 & & & \\
\hline
\end{tabular}

a. Predictors: (Constant), IImuPengetahuan, MinatdanBakat, Motivasi

b. Dependent Variable: KeberhasilanBerwirausaha
Dari Uji ANOVA atau Uji F dalam Tabel 4.3 diatas dapat diketahui bahwa nilai sig dari $\mathrm{F}$ hitung $0,000<0,05$ maka $\mathrm{H}_{0}$ dapat ditolak pada derajat kepercayaan $\alpha=0,05$. dengan kata lain, hipotesis alternatif $\left(\mathrm{H}_{1}\right)$ diterima, yang menyatakan bahwa semua variabel independen secara serentak dan signifikan mempengaruhi variabel dependen.

2. Uji Signifikansi Parameter Individual (Uji Statistik t)

Dilakukan untuk menguji apakah masingmasing variabel independen mempunyai pengaruh yang signifikan terhadap variabel dependennya.Uji $t$ dalam penelitian ini meliputi minat dan bakat, motivasi dan ilm pengetahuan sebagai variabel independen dan keberhasilan berwiausaha sebagai variabel dependennya. Untuk melihat besarnya pengaruh digunakan angka beta atau Standartize Coefficient yang ditunjukkan pada tabel berikut :

\begin{tabular}{|c|c|c|c|c|c|c|}
\hline \multicolumn{7}{|c|}{ Coefficients ${ }^{8}$} \\
\hline & & \multicolumn{2}{|c|}{$\begin{array}{c}\text { Unstandardized } \\
\text { Coefficients }\end{array}$} & \multirow{2}{*}{$\begin{array}{c}\text { Standardized } \\
\text { Coefficients }\end{array}$} & \multirow[b]{2}{*}{$T$} & \multirow[b]{2}{*}{ Sig. } \\
\hline \multicolumn{2}{|c|}{ Model } & $B$ & Std. Error & & & \\
\hline \multirow[t]{4}{*}{1} & (Constant) & 42.211 & 12.652 & & 3.336 & .000 \\
\hline & MinatdanBakat & .199 & .074 & .128 & 11.334 & .001 \\
\hline & Motivasi & .388 & .115 & .160 & 11.636 & .002 \\
\hline & IImuPengetahua & .270 & .068 & .244 & 12.499 & .001 \\
\hline
\end{tabular}

a. Dependent Varible: Keberhasilan Berwirausaha

Berdasarkan tabel diatas pada kolom Unstandartized Coefficient digunakan untuk membuat persamaan regresi. Karena nilai konstanta (constant) $=$ 42.211 dan nilai untuk minat dan bakat $=$ 0,199, motivasi $=0,388$, dan ilmu pengetahuan $=0,270$ maka persamaan regresi untuk variabel minat dan bakat $\left(\mathrm{X}_{1}\right)$, motivasi $\left(\mathrm{X}_{2}\right)$,ilmu pengetahuan ( $\mathrm{X}_{3}$ ), serta keberhasilan berwirausaha ( $\mathrm{Y}$ ) tersebut dapat ditulis persamaan regresi sebagai berikut :

$$
Y=42.211+0,199 X_{1}+0,388 X_{2}+0,270 X_{3}+e
$$

Keterangan

$\mathrm{Y}=$ Keberhasilan Berwirausaha

$\alpha=$ Bilangan konstanta

$1 \beta \ldots n \beta=$ Koefisien arah regresi

$\mathrm{X} 1=$ Minat dan Bakat

$\mathrm{X} 2$ = Motivasi

$\mathrm{X} 3$ = Ilmu pengetahuan

Berdasarkan hasil Uji t yang dilakukan dalam penelitian ini yaitu dengan membandingkan nilai $t_{\text {hitung }}$ dengan $t_{\text {tabel }}$. Jika $t_{\text {hitung }}$ lebih besar dari $t_{\text {tabel }}$ maka dapat disimpulkan terdapat pengaruh dari variabel yang satu terhadap variabel yang 
lainnya.t $t_{\text {tabel }}$ di dapat dengan melihat tabel t dengan ketentuan sebagai berikut :

$$
\mathbf{d k}=\mathbf{n}-\mathbf{k}
$$

karena jumlah variabel $(\mathrm{k})$ adalah 3 , dan jumlah responden (n) dalam penelitian ini adalah 105, maka :

$$
\begin{aligned}
\mathbf{d k} & =105-2 \\
& =103
\end{aligned}
$$

sehingga didapat nilai $\mathrm{t}_{\text {tabel }}$ adalah sebesar 1,918

Nilai $t_{\text {hitung }}$ untuk variabel minat dan bakat adalah sebesar 11,334 dengan taraf signifikan sebesar $0,001<0,05$. Hal ini menunjukkan bahwa $t_{\text {hitung }}$ lebih besar dari $t_{\text {tabel }}(11,334>1,918)$, artinya terdapat pengaruh yang signifikan dari variabel minat dan bakat terhadap keberhasilan berwirausaha atau dapat dikatakan bahwa hasil penelitian ini menolak $\mathrm{H}_{0}$ (minat dan bakat berpengaruh negatif terhadap keberhasilan berwirausaha) dan menerima $\mathrm{H}_{1}$ (minat dan bakat).

\section{DAFTAR PUSTAKA}

Maslow, Abraham H, Motivasi dan Kepribadian, Teori Motivasi dengan Pendekatan Hierarki Manusia, Seri Manajemen No. 104.APPM, 1996.

Hisrich, Robert D., Peter, Michael P., Entrepreneurship: Strating, Developing, and Managing a New Entreprise, Irwin, Mc Grawhill Companies, 1995

Muchamad Arif Mustofa, Pengaruh Pengetahuan Kewirausahaan, Selfefficacy dan Karakter Wirausaha terhadap Minat berwirausaha pada siswa kelas XI SMK Negeri 1 Depok( Skripsi Universitas Negeri Yogyakarta, 2014,12)

Paulus aditama, Faktor-faktor yang mempengaruhi minat berwirausaha( studi kasus mahasiswa fakultas ekonomi dan bisnis Undip,Semarang) (Skipsi Universitas Diponegoro Semarang 2014,21.

Slameto,(2015). Belajar dan factor-faktor yang mempengaruhinya. Cetakan keenam . Jakarta. PT. Rineka CIpta.

Sugiyono, 2013. Statistika Untuk Penelitian. Bandung: CV. Alfabeta

Suhartini, Yati. 2011. Analisis factor- factor yang mempengaruhi minat mahasiswa dalam Berwirausaha. Jurnal Akmenika UPY.Vol. 7,2011

Suryana, Kewirausahaan, Salemba Empat, Jakarta, 2010.

Thomas W Zimmerer, Norman M. Scarborough, Entrepreuneurship and The New Venture Formation,Prentice Hall International Edition,New Jersey, 1996.

\section{Profil penulis}

Fibria Anggraini Puji Lestari, Program Studi Informatika Universitas Indraprasta PGRI Jl. Nangka No. 58 C (TB. Simatupang), Kel. Tanjung Barat, Kec. Jagakarsa, Jakarta Selatan 12530.

Email : fap102@yahoo.com 